\title{
SOCIETAL ECONOMICS OF THE EUROPEAN UNION LIQUID FUEL CONSUMPTION FOR ROAD TRANSPORTATION
}

\author{
Alfred Wong* \\ Arbokem Inc., Vancouver, Canada
}

In order for the EU to achieve its goal of $10 \%$ biofuel for all $\mathrm{EU}$ motor vehicles by 2020, a substantial amount of biofuel as well as a biofuel feedstock would need to be imported largely from developing countries where the climate is warm and labor is inexpensive. But there may never be sufficient supply to fulfill the evergrowing demand for biofuel for road transportation in the EU, even as motor vehicles are increasingly becoming more fuel-efficient. The constraint to realizing an effective and equitable reduction in greenhousegas emission is the overbearing political economics of neoliberalism. A different remedial strategy is needed to address the dual problems of the excessive uses of motor fuels and greenhouse-gas emission.

Keywords: biofuel, energy, exploitation, greenhouse gas, lifestyle, transportation

JEL Classification: 033, 052, P28, Q54

\section{INTRODUCTION}

In 2009, the European Commission (EC) issued Directive 2009/28/EC to achieve the goal of the „10\% biofuel" component in motor fuels used in the transportation sector of the European Union (EU) by 2020 (European Commission - EC, 2009). The aim of the official policy was to curb $\mathrm{CO}_{2}$ emission ${ }^{1}$ from, among other things, road-transport vehicles, largely by the increased use of biomass-derived fuels.

In the implementation of this Directive, the adequate supply of the bio-based feedstock was found quickly to

\footnotetext{
* Correspondence to: A. Wong, Arbokem Inc., Post Office Box 34173, Vancouver V6J 4N1, Canada; e-mail: arbokem@arbokem.com
}

be especially problematic. Trade liberalization within the biofuel sector has been cited to help improve competition and consequently improve efficiency and decrease production costs with little or no consideration of externalities (Stockholm Environment Institute - SEI, 2008). There has been considerable discourse for many years about the dark side of the biofuel policies of developed economies (Borras, McMichael \& Scoones, 2011).

The perplexing question is why the EC chose and maintained a steadfast course to rely on the biofuel usage in providing a significant reduction in GHG emission. Concomitantly significant externalities were conveniently ignored, even though the reduction of GHG emission is knowingly global, and not regional 
in nature. To date, the quantification of the societal impact of the biofuel supply and the operating rules has not been meaningful as it serves largely to justify the present modality of profit-driven industrial practices. Moreover, most EU-funded activities are regrettably directed towards the creating of an ever larger and less costly supply of biofuel, especially in overseas locations, for its importation to Europe.

This study is aimed to illustrate the futility and deficiency of the current EU strategy in reducing $\mathrm{CO}_{2}$ emission in the transportation sector under the present economic paradigm. The suggestions of the ways and means to remedy these notable deficiencies are going to be offered.

The statistical data published by the United Nations were deployed for the analysis of the motor fuel used for road transportation in the European Union, and the selected countries in Asia, Africa and Latin America. The last year in which the fuel consumption data were available in full was 2010. The Human Development Index (HDI) ${ }^{2}$, published annually by the United Nations Development Program (UNDP, 2014), was used as a convenient means to depict the quantity and quality of the lifestyle at the nation state level.

\section{THE ANALYSIS}

\section{Liquid fuels manufacturing technology}

Traditionally diesel (also known as gas oil) and gasoline are produced by the distillation of crude petroleum in chemical refineries. The quality of the feedstock is an important factor affecting the fraction of diesel and gasoline that could be produced optimally. Moreover, the proportion of diesel and gasoline produced is varied according to regional demand seasonally.

There are many commercial and experimental technologies for the conversion of solid or liquid biomass to a liquid fuel for road transportation uses. Technologies for the large-scale direct conversion of surplus biomass such as residues from forestry operations and agricultural cropping into a liquid feedstock continue to be complex, capital intensive and somewhat energy inefficient. Figure 1 illustrates the principal pathways of producing a liquid fuel from biomass. For diesel fuel vehicles, an oily feedstock such as rapeseed oil or crude palm oil is generally deployed. For gasoline, plant saccharides such as hexoses and pentoses are the usual starting raw materials.

\section{The biofuel feedstock supply}

It has been widely known for some time that there is insufficient arable land available within the EU to supply the projected feedstock demand, without affecting the present pattern of cereal grain production for food (De Wit, Faaij, Fischere, Prieler \& van Velthuizen, 2007; Fischer, Prieler \& van Velthuizen, 2007). One element of the EU biofuel strategy was thus to import a voluminous amount of its biofuel requirement to make up for the substantial shortfall in the feedstock for domestic biofuel production. Because of the large volume of biofuel required in the EU, only mass-scale plantations elsewhere would be practical to provide the tanker shipment of a bio-oil feedstock and/ or a finished biofuel to the EU.

\section{Societal destruction}

Since 2009, this import strategy has caused notably massive ecological destruction. Large amounts of land have been and are still being cleared in tropical countries to plant the monoculture oil palm (Elaeis guineensis Jacq.) for a feedstock (oil) export to the $\mathrm{EU}$ for its subsequent conversion to bio-diesel fuel. In Indonesia, large tracts of intact virgin forests (especially in Sumatra and Kalimantan) are being destroyed intentionally in order to be re-labeled as "degraded land eligible for rehabilitation" into monoculture palm oil plantations (Klawitter, 2014). In Colombia and elsewhere in Latin America, the seizure of land with the resulting destruction of the indigenous communities is common practice in the national pursuit of the development of palm oil export to the EU (Anon, 2008).

In the gasoline sector, the conversion of nominally "under-utilized" land for sugar-cane cropping for the subsequent production of ethanol has a similar negative social-cultural impact. The deplorable 




Figure 1 Example technology pathways for powering liquid-fuel transportation vehicles

Source: Author

widespread violation of human rights in the operation of massive sugar-cane plantations in Brazil for the export of ethanol to the EU is largely ignored by the
EC (Kenfield, 2008). Separately, the allocation of arable land for the production of maize or sugar cane for the subsequent manufacture of ethanol has also been 
associated with increasing food prices (Brodzinsky, 2013). As a comparison, the ethanol biofuel industry in the USA has grown to become self-perpetuating in the national political economy (Magdoff, 2008). In consideration of all externalities, the use of ethanol biofuel in advanced economies may have little or no direct impact on the net reduction in the global GHG emission. Trade and commerce are paramount über alles.

Because of the acute shortage of arable land within the territories of the present EU member states, Ukraine with a vast tract of rich black soil used presently for cereal grain cropping has become a strategic target to be requisitioned for the cultivation of biofuel crops. This land-control ambition was already revealed some years ago, prior to the issuance of Directive 2009/28/ EC (De Wit et al, 2007; Fischer et al, 2007). The recent "provocative measures to capture Ukraine into the EU political sphere" might be a manifestation of the grand design of creating an "agricultural appendage of Europe" for the biofuel supply (Anon, 2014).

The foundation of supplying biofuel (i.e. a feedstock and/or a finished product) from less economicallydeveloped countries (LEDCs) to the EU is inherently very destructive for feeding the insatiable biofuel appetite of the EU-15 states (Wong, 2008; Wong \& Ching, 2009). The fundamentals of an abundant lowcost feedstock (as well as finished biofuel) are cheap labor and low-cost land.

\section{Public discourse}

The European Commission has recently conceded that the 2009 biofuel Directive has to be modified to dampen the exploitative practices in the "get rich quick" schemes of supplying a biofuel feedstock (as well as biofuels) to the EU. Despite this belated recognition of the short-comings, the allowance of "food-based biofuels" has somehow increased from the original $5 \%$ to $7 \%$ of the "10\% biofuels" target set for the transportation sector in 2009. In practice, no EU farmers would be left stranded as more rapeseedderived diesel fuel could be admitted into this increased quota. This counter-reform appeared to have been the result of intensive lobbying by the established biofuel and agricultural business sectors (Mathiesen, 2013).

Setting a new „carbon" baseline of motor fuel qualities and accounting the indirect land use conversion ${ }^{3}$ (Havlík, Schneider, Schmid \& Bottcher, 2011; Ahlgren \& Di Lucia, 2014) are among the various issues being contemplated in order to address the earlier policy deficiencies. Specifying a low "carbon baseline” of motor fuel qualities ${ }^{4}$ would allow many more existing biofuel production schemes to qualify for approved GHG reduction accounting. It is generally recognized that the indirect land use could not be quantified with any degree of enduring reliability (Broch, Hoekman \& Unnasch, 2013). Moreover, it is highly contentious that the quantification of cultural values and the social structure could and should be monetized for the calculation purposes.

In the present deliberation of the biofuel policy improvements, the consequential societal impact in less-developed supplier countries has continued to be considered largely within the framework of neoliberal economics (van der Horst \& Vermeylan, 2011). Meaningful rectification is fraught with considerable difficulties from competing commercial interests. The discourse within the EU appears to have thus steadily been reduced to a "numbers game" (Hennecke, Faist, Reinhardt, Junquera, Neeft \& Fehrenbach, 2013), which may even not have any bearing on the absolute reduction required in the sectoral emission of GHG.

While the EC, academia and interested business entities debate the various contending issues, social and ecological destruction in LEDCs continues unabated.

\section{The disparate consumption of fuel for road transport}

The root cause of the problem may be the exorbitant consumption of motor fuels. Figure 2 shows that the per capita consumption of the transportation fuel ${ }^{5}$ of the EU-15 member states ${ }^{6}$ is disproportionately higher than that of the selected countries in Latin America, Africa and Asia. In the present comparison, certain large countries on these continents, i.e., Brazil in Latin America, South Africa in Africa, and India and China in Asia, were purposely excluded in order to avoid a 
potential problematic distortion of the representative statistics. This gross difference in per capita consumption reflects directly in the disproportionate emission of anthropogenic $\mathrm{CO}_{2^{\prime}}$ arising from the use of the petroleum-based fuel for road transport.
Note that the 2010 consumption of the road-transport fuel in Germany was nearly 5 times higher than that of Vietnam. Germany had nearly the same population as Vietnam of about 85 million in 2010. Why is the transportation fuel consumption so high?

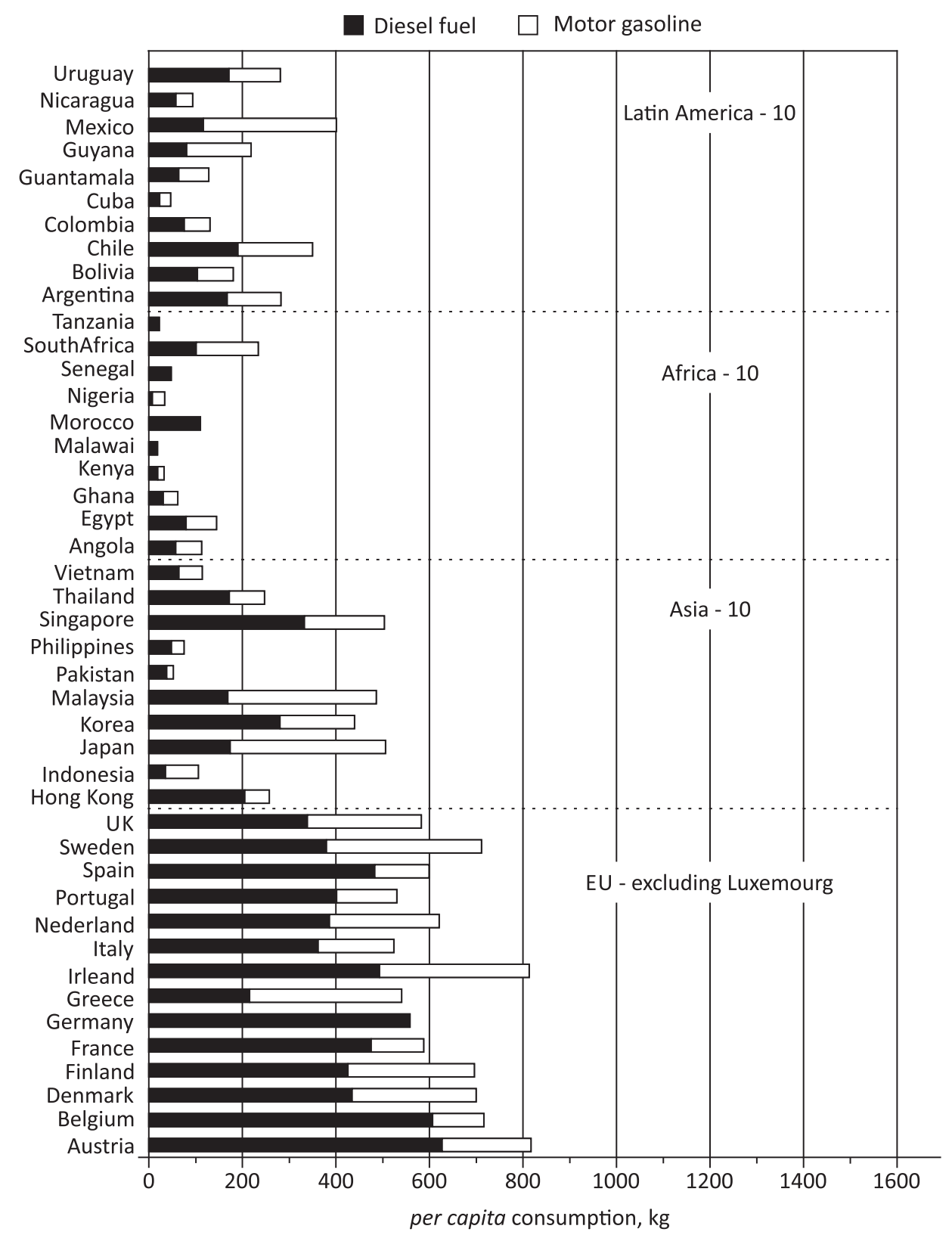

Figure 2 The per capita consumption of diesel and motor gasoline in the selected countries in 2010 (the latest data year available) 
The data given in Table 1 suggest that a probable cause is the extensive use of private vehicles for daily transportation. General resistance to a substantial reduction in $\mathrm{CO}_{2}$ emission from this source may be due to the "energy-intensive life style" the Europeans are reluctant to relinquish. Certainly, the ownership of an automobile (with attendant at-will uses) is an entrenched entitlement of EU citizens.

Klein (2014) argued that capitalism and climatechange mitigation are irreconcilable adversaries. This proposition is true in view of the sole legally-mandated mission of modern corporations (with the government assistance $^{7}$ ) to make profit for shareholders in the near term. Klein (2014) decried that there are still ardent vocal "climate-change deniers" among governmental and corporate leadership. This observation may be of incidental relevance. Above all else, the guiding principle is to make money quickly regardless of future consequences of any kind. The reality is that corporate executives are not rewarded financially for corporate performance in the far distant future. Predicted global catastrophe arising for a warming global climate in 2050 is definitely not and could not be in most corporate planning horizon. The exception is of course corporations which can profit immensely from climate-change disasters (Klein, 2007).

Table 1 Passenger mobility in the selected EU-15 member states, circa 2006

\begin{tabular}{l|lll}
\hline & $\begin{array}{l}\text { The average } \\
\text { number of } \\
\text { trips/person/ } \\
\text { day }\end{array}$ & $\begin{array}{l}\text { The average } \\
\text { travel distance } \\
(\mathrm{km}) / \text { person/ } \\
\text { day }\end{array}$ & $\begin{array}{l}\text { The average } \\
\text { travel time } \\
\text { (minutes)/ } \\
\text { person/day }\end{array}$ \\
\hline Austria & 3.0 & 28.1 & 68.8 \\
Finland & 2.9 & 41.8 & 70.7 \\
France & 2.9 & 35.3 & 58.2 \\
Germany & 3.3 & 36.9 & 80.0 \\
Netherland & 3.1 & 31.9 & 59.9 \\
United & 2.9 & 31.8 & 63.3 \\
Kingdom & 2.9 & &
\end{tabular}

Source: de la Fuenete Layos, 2007
Figure 3 illustrates that HDI correlates well with transportation fuel consumption. It is interesting to note that the per capita consumptions in Austria and Ireland in 2010 are the highest in the EU-15 member states. It is evident that, as developing countries advance in HDI, transportation fuel consumption could be expected to rise sharply. The foremost question is whether this future pattern of fuel consumption is environmentally sustainable as LEDCs advance upwards on the HDI scale. It would appear that the only viable path to break this projected outcome would be to have the top HDIranked countries reduce their per capita consumption aggressively.

Does a substantial reduction in the petro-fuel usage in the transportation sector affect the "quantity and quality of life" in the EU-15? The data provided in Table 2 suggest that human well-being does not necessarily need to be reduced substantially by a significant reduction in the per capita usage of motor fuel. Note that Japan has a high HDI comparable to that of the EU-15 member states. If the Japanese per capita consumption of fuel for road transport had been used as the benchmark for the EU-15 member states, the total annual 2010 consumption for the EU-15 would have been about 200,000 million tonnes of diesel + gasoline, which is about 16\% less than the 2010 EU-15 base case. It follows that an absolute reduction in the usage of motor fuel, for example, a $20 \%$ decrease from the 2010 base line as the starting point, would appear to be very practicable in the EU-15 states. A threat of the degradation of the "lifestyle" could effectively be non-existent, even within the framework of prevailing neoliberal economics.

\section{An effective remedial action}

Although the urgent need to reduce GHG emission is gaining widening recognition, the real-time reduction in the accustomed entitlement of the pleasurable goods and services of the EU public at large is a formidable undertaking. In essence, the government's climatechange policy's options are nearly always developed within the framework of neoliberal economics, in precedence over truly-needed effective remedial actions. 


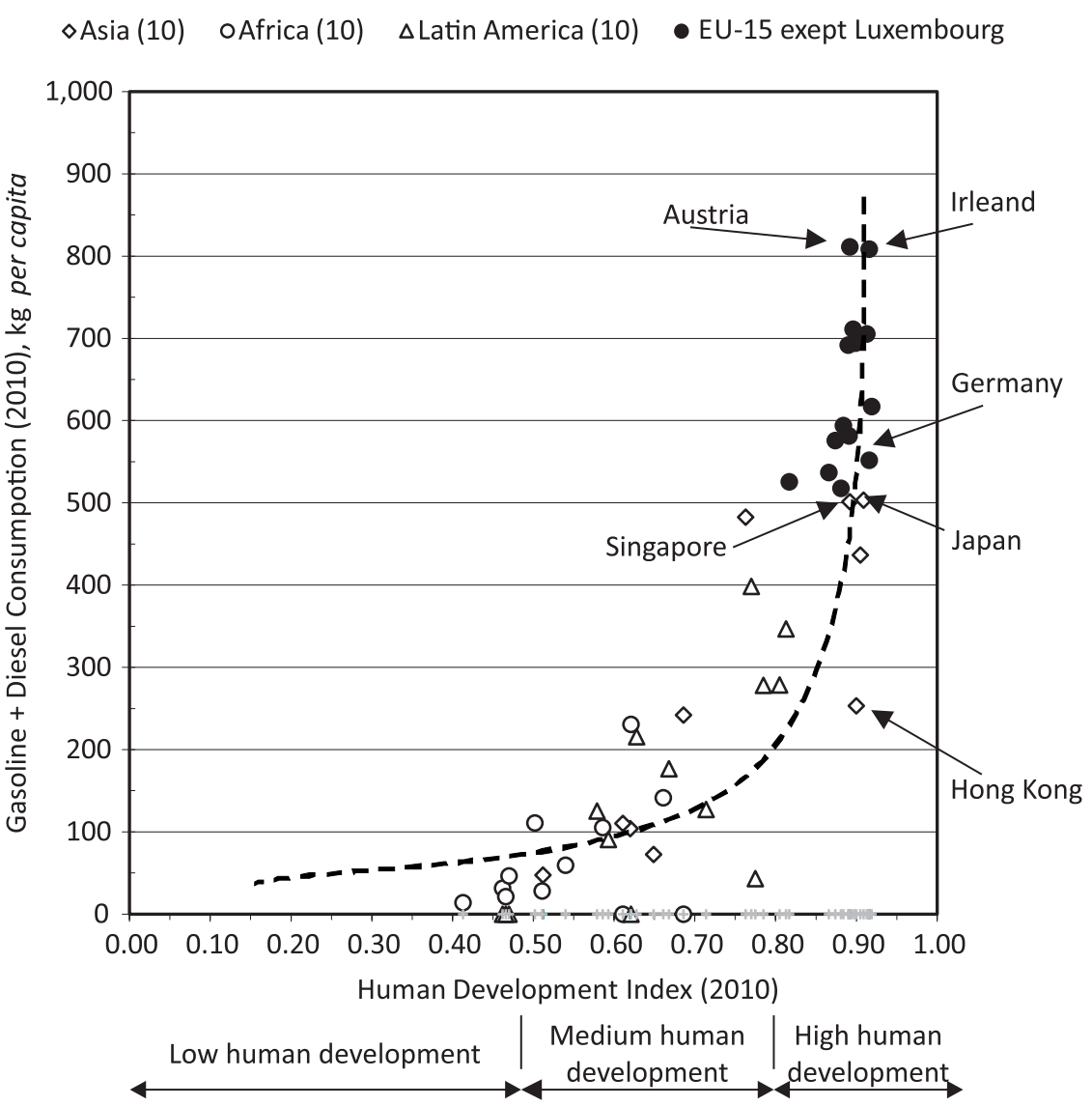

Figure 3 Per capita transportation fuel consumption and the Human Development Index

Source: Author

Table 2 Transportation fuel consumption and human well-being in the selected G-7 nations

\begin{tabular}{l|cccc}
\hline $\begin{array}{l}\text { The } 2010 \\
\text { database }\end{array}$ & Human well-being & $\begin{array}{r}\text { The total transport } \\
\text { fuel consumption } \\
\text { litres per } \\
\text { capita }\end{array}$ & \% of Japan \\
\hline Japan & 0.909 & -- & 503 & --- \\
France & 0.891 & 98 & 581 & 116 \\
Germany & 0.916 & 101 & 552 & 110 \\
Italy & 0.881 & 97 & 518 & 103 \\
$\begin{array}{l}\text { United } \\
\text { Kingdom }\end{array}$ & 0.874 & 96 & 576 & 114 \\
\hline
\end{tabular}

Source: UNDP, 2014; UNSD, 2015

\section{Classical tools}

The development of conventional fiscal tools such as fuel taxes has yet to substantially result in curbing motor-fuel demand. Higher prices at the pump would merely be transferred into an increased demand for a higher income from workers at large to compensate for the "higher cost of living". The net demand for transportation fuel would thus remain largely unchanged. Taxation is generally recognized to be a pre-eminent tool to raise revenue for the government; it is rarely effective for curbing demand for consumer goods.

Table 3 shows that the total consumption of combined diesel and gasoline apparently declined in the EU-15 by about 7\% between 2005 and 2010. The discretionary spending style of the people of these 
Table 3 Fuels used for road transport in the EU-15 in 2005 and 2010

\begin{tabular}{l|ccccccc}
\hline 1,000 tonnes & \multicolumn{2}{|c}{ Gas oil - diesel } & \multicolumn{2}{c}{ Motor gasoline } & \multicolumn{2}{c}{ Diesel + gasoline } \\
& 2005 & 2010 & 2005 & 2010 & 2005 & 2010 & \% of 2005 \\
\hline Austria & 5,553 & 5,187 & 2,078 & 1,620 & 7,631 & 6,807 & 89 \\
Belgium & 6,195 & 6,538 & 1,762 & 1,211 & 7,957 & 7,749 & 97 \\
Denmark & 2,067 & 2,381 & 1,837 & 1,471 & 3,904 & 3,852 & 99 \\
Finland & 2013 & 2,264 & 1,739 & 1,447 & 3,752 & 3,711 & 99 \\
France & 29,918 & 30,701 & 10,473 & 7,114 & 40,391 & 37,815 & 94 \\
Germany & 25,089 & 26,875 & 22,968 & 18,259 & 48,057 & 45,134 & 94 \\
Greece & 2,055 & 2,392 & 3,888 & 3,680 & 5,943 & 6,072 & 102 \\
Ireland & 2,251 & 2,186 & 1,710 & 1,432 & 3,961 & 3,618 & 91 \\
Italy & 22,527 & 21,639 & 13,488 & 9,678 & 36,015 & 31,317 & 87 \\
Luxembourg & 1,794 & 1,731 & 500 & 350 & 2,294 & 2,081 & 91 \\
Netherlands & 6,256 & 6,290 & 4,097 & 3,965 & 10,353 & 10,255 & 99 \\
Portugal & 4,099 & 4,212 & 1,808 & 1,380 & 5,907 & 5,592 & 95 \\
Spain & 23,216 & 22,060 & 7,260 & 5,311 & 30,476 & 27,371 & 90 \\
Sweden & 3,004 & 3,520 & 3,862 & 3,096 & 6,866 & 6,616 & 96 \\
Britain & 19,436 & 20,873 & 18,731 & 14,988 & 38,167 & 35,861 & 94 \\
Total & 155,473 & 158,849 & 96,201 & 75,002 & 251,674 & 233,851 & 93 \\
\hline
\end{tabular}

Source: UNSD, 2015

countries was notably reduced during the past few years of economic depression. However it is almost certain that the previous trend of the ever-increasing demand for motor fuel for the transportation sector is going to resume rising again steadily in the near future as the consumption-based economy recovers. The comparison of the data given in Figure 3 (for 2010) and Figure 4 (for 2005) shows the unchanged relative position of the EU-15 member states on the HDI and motor fuel consumption scales. The per capita consumption remains substantially static in the selected Asian, African and Latin American countries, during this period of global economic depression, as changes in these very low "subsistence level” figures were not readily appreciable.

The European Commission is also relying on the strategy of improving the fuel efficiency of motor vehicles as an additional measure to reduce overall fuel consumption. Improving the fuel efficiency of motor vehicles might be reaching an asymptotic technical limit. The formidable technical barriers include:

- a minimum kinetic friction required between the tires and the road surface for adequate vehicle stability during its traveling,

- a non-zero frontal shape factor in the vehicle design,

- the minimum vehicle weight from metal, glass and plastic components, and

- a non-zero passenger weight.

The basic laws of Newtonian physics dictate the mandatory application of a certain minimum energy input for motion against friction. 


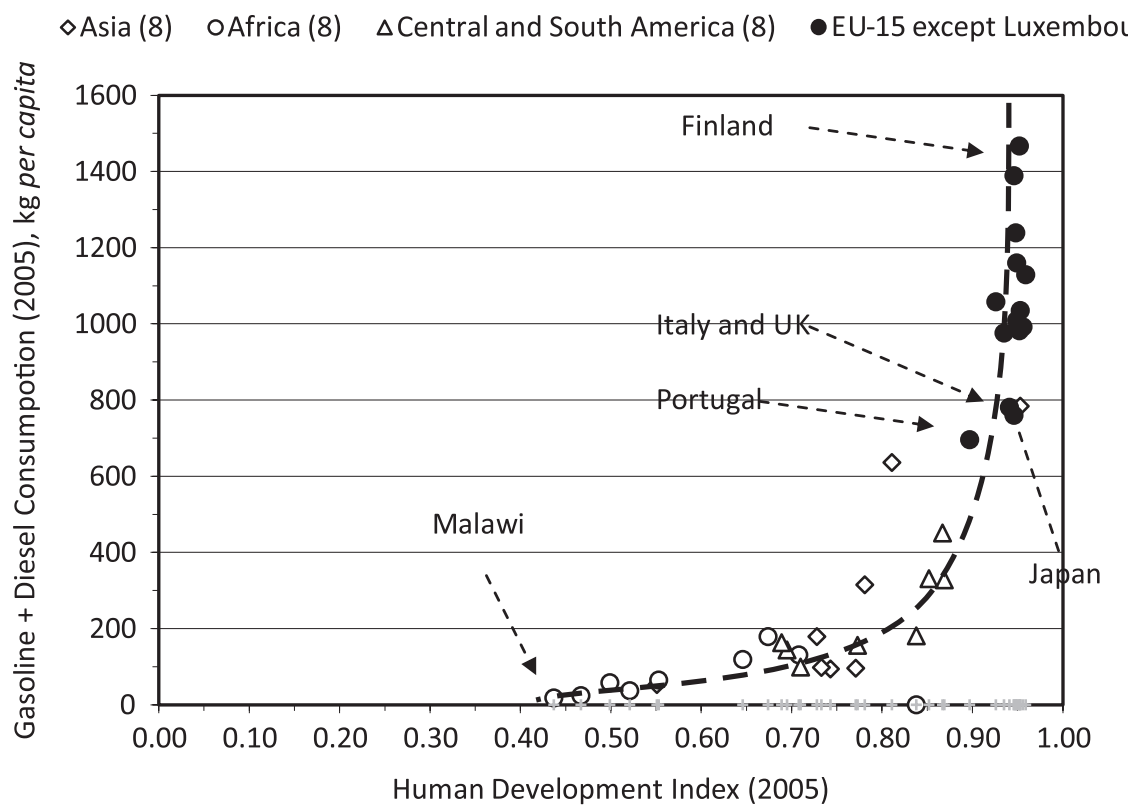

Note: ( ) the number of the countries included in the illustration

Figure 4 Motor fuel consumption and the 2005 Human Development Index

Source: Author, based on: Wong \& Ching, 2009

\section{Absolute reduction}

The Intergovernmental Panel on Climate Change IPPC (2014) has recently projected that a reduction of at least 50\% in GHG emission by 2050 (from the 2010 level) will likely be required to suppress the critical atmospheric $\mathrm{CO}_{2}$ level to below 530 parts per million. In other words, a $50 \%$ reduction in the fossil fuel usage will be needed. What is thus needed is a drastic action to reduce the overall per capita consumption of petrofuel consumption to effect the essential reduction in the motor-vehicle emission of $\mathrm{CO}_{2}$. Figure 5 shows that the net impact of several policy options for responding to the urgent need to reduce the overall GHG emission expeditiously. In the implementation of Directive 2009/28/EC, neither the economic growth model ${ }^{8}$ nor the population growth model ${ }^{9}$ would be adequate. The absolute consumption of motor fuels is projected to continue rising substantially in the future years. An aggressive reduction in such a usage might reasonably be concluded to be the only effective means to achieve a tangible decrease in $\mathrm{CO}_{2}$ emission. If this societal
„50\% reduction" goal were adopted, one could expect that the transportation sector would be required to decrease its emission proportionately, in relation to other economic sectors. It follows that only an absolute reduction in the usage of transportation petro-fuel could meet the desired EU-wide target.

The mandatory expansion of the biofuel substitution beyond Directive 2009/28/EC is not feasible, in view of the manifestation of the numerous widely-recognized negative social, cultural and ecological consequences worldwide. The International Energy Agency (2015) has recently urged more spending on research in and the development of renewables in order to reduce the dependency on petro-fuel by $50 \%$ prior to 2050 . The report had few or no comments on the need to reduce the absolute consumption of energy products. Essentially, the promoted task is to create more "green" energy for more consumption. "Green" growth is essentially nonsense, without curbing the underlying demand. Because of the already discussed limitations of an expanded biofuel development, electric power 


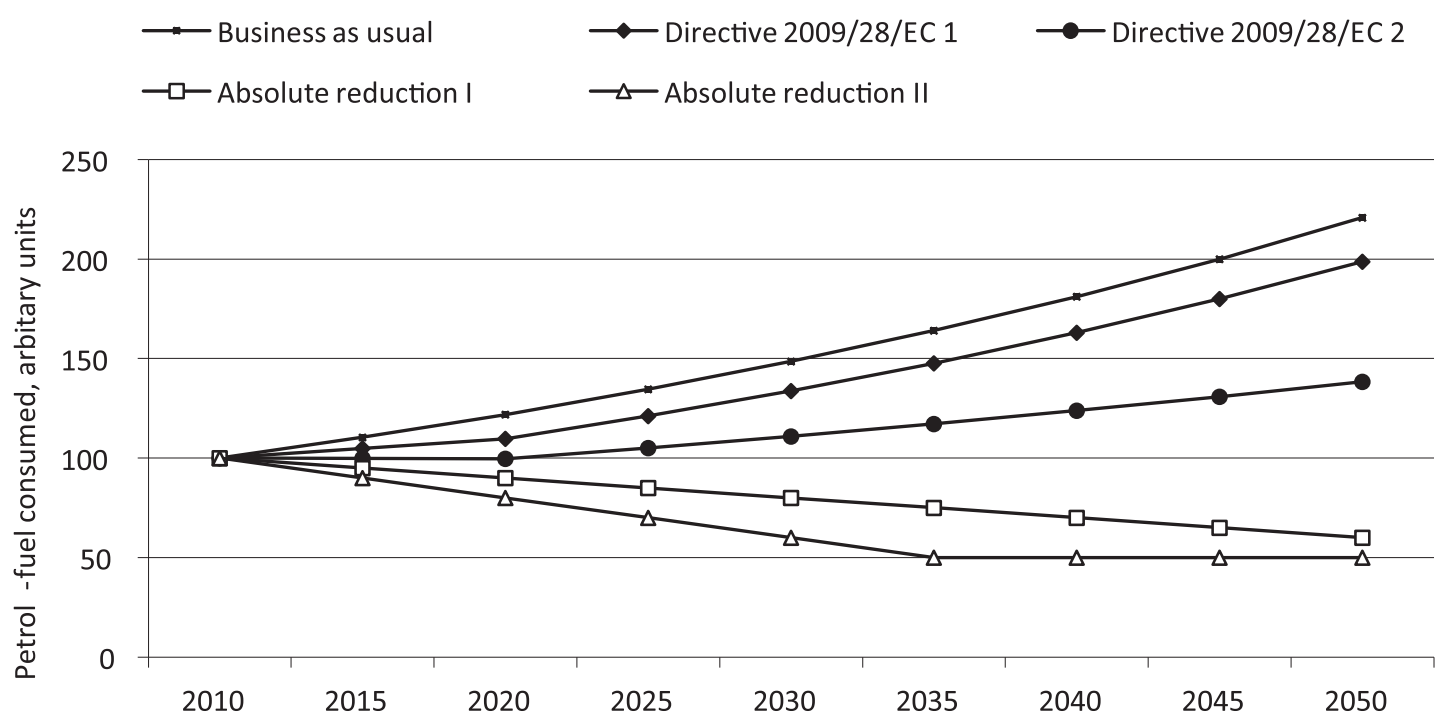

The petro-fuel reduction schedule:

\begin{tabular}{|c|c|c|c|c|c|c|c|c|c|}
\hline Scenario (\% from 2010 baseline) & 2010 & 2015 & 2020 & 2025 & 2030 & 2035 & 2040 & 2045 & 2050 \\
\hline \multicolumn{10}{|l|}{ Business as usual (unvarying $2 \%$} \\
\hline annual real economic growth) & 0 & 0 & 0 & 0 & 0 & 0 & 0 & 0 & 0 \\
\hline $\begin{array}{l}\text { Directive } 2009 / 28 / E C 1 \text { (based on the } \\
\text { unvarying } 2 \% \text { annual real economic growth } \\
\text { model) }\end{array}$ & 0 & 5 & 10 & $10^{*}$ & 10 & 10 & 10 & 10 & 10 \\
\hline $\begin{array}{l}\text { Directive } 2009 / 28 / E C 2 \text { (based on the } \\
\text { projected population growth model) }\end{array}$ & 0 & 5 & 10 & $10^{*}$ & 10 & 10 & 10 & 10 & 10 \\
\hline $\begin{array}{l}\text { Absolute reduction I (assuming no regulatory } \\
\text { demand for biofuel substitution) }\end{array}$ & 0 & 5 & 10 & 15 & 20 & 25 & 30 & 35 & 40 \\
\hline $\begin{array}{l}\text { Absolute reduction II (assuming no } \\
\text { regulatory demand for biofuel substitution) }\end{array}$ & 0 & 10 & 20 & 30 & 40 & $50 \#$ & 50 & 50 & 50 \\
\hline
\end{tabular}

Notes:

* assuming the „10\% biofuel substitution” rule remains unchanged after 2020

\# assuming no further annual decrease after the $50 \%$ reduction (relative to 2010 level) goal has been reached

Figure 5 The projection of the impact on the usage of petro-fuel by the selected policy choices

Source: Author

generation might be the only other option available for powering motor vehicles. This strategy is, however, likely to be fraught with many problems because of the various negative ancillary factors such as massive landscape desecration for wind power and solar power generators, the unresolved safe disposal of radioactive wastes from nuclear power plants, the unbridled commercial exploitation of mineral resources for the manufacture of solar receptor panels and battery storage hardware etc. Even with additional 
„innovative research tinkering", most other practicable technologies such as fuel-cell, geothermal power, hydroelectric power and tidal power have essentially the same non-zero societal and ecological drawbacks in their implementation.

In retrospect, the present biofuel policy of, $10 \%$ substitution" has largely been a futile exercise, in view of the growing absolute consumption of petro-fuel for transport with an ensuing increased $\mathrm{CO}_{2}$ emission. To date, the only certain outcome of the Directive 2009/28/EC has been the one that many companies and individuals have become economically wealthier. This outcome is of course not unexpected in the neoliberal economic sphere (Teeple, 1995). An alternative drastic measure might be to allocate transportation fuel on a per capita basis. Unfortunately, this step could never be undertaken as it contravenes the foundational economic model of the European Union (EU, 2015). What has remained undisclosed is the fact that the underlying founding principles of the EU were, among other things, ,...the containment of socialism, and the furtherance of liberal political and legal principles,..." (Teeple, 1995, 58). In essence, free-market capitalism is the only permitted framework for the EU policies. There is thus no possibility that strict adherence to this foundational principle would afford any significant decrease in GHG emission. Under these structural constraints, it is disingenuous for the European Commission to promulgate its remedial policies (directives etc.) for this purpose.

\section{Public transit}

Improved public transit could offer an effective realtime means to reduce fuel consumption for road transport. Practicable remedial actions inside the EU-15 might emulate those of Hong Kong (the 2013 population: 7 million; exemplifying highly-populated small land-based states) and Japan (the 2013 population: 127 million; exemplifying highly-populated large land-based states), where efficient land-based public transit systems are intensively developed. For example, at the end of 2013, there were 12 rail lines operating in the Hong Kong territory (Government of the Hong Kong Special Administrative Region - GHK-SAR, 2014) to serve the total land area of $\sim 1,100 \mathrm{~km}^{2}$. Five additional urban rail projects are being planned for completion by 2020. The similar intensification of the urban transportation network could be undertaken by many mega-cities in the EU as an aggressive means to reduce personal car-use substantially. Note that this approach does not prevent anyone from owning a private vehicle for their personal transportation. This alternative strategy provides considerable incentives for reducing the use of private vehicles.

In Germany, instead of the relentless drive to privatize the national railway system for perhaps manufactured reasons, the publicly-owned Deutsche Bahn ${ }^{10}$ should be provided with several billion Euros of annual operating fund by the Bundesrepublik Deutscheland for the immediate reduction of fares for regional and long-distance travel. For reasons of personal finances, the general population could be expected to adopt substantially and almost immediately a greater use of public transportation, if the fare were reduced significantly (perhaps to zero), the frequency of service substantially increased and the service network considerably expanded. In essence, one of the most effective means to reduce a greenhouse gas emission from the burning fuel for road transportation is to retain and operate the public transportation system as a "public good".

Private enterprise (for example, a privatized Deutsche Bahn) could not be expected to provide the transportation services for the collective public good. After all, the sole purpose (mandate) of a corporation is to generate the maximum profit for its shareholder. There is no other corporate mission (Friedman, 1970). The current drive to the privatization of the public services is actually contrary to the goal of a significant reduction in $\mathrm{CO}_{2}$. There is no logical assurance that privatized public transportation would afford a higher public usage of transit for the reduction in $\mathrm{CO}_{2}$ emission in road transportation.

Where would the funding for enhanced public transit come from? One obvious source is the $\sim € 37$ billion ${ }^{11}$ officially consumed by the Bundeswehr in the example 2010 (Stockholm International Peace Research Institute - SIPRI, 2014). Because of the various dualuse research assistance and the industry support programs, the actual total military expenditures may 
be considerably higher. The anti-USSR Cold War was stopped more than two decades ago. Coincidentally, a one-third reduction in the Bundeswehr official budget would provide free rail transportation for everyone in Germany.

Diverting the military budget for $\mathrm{CO}_{2}$ reduction in road transportation could easily be adopted by all the EU member states without recourse to higher direct or indirect personal (or corporation) taxation. Although the European Defence Agency - EDA vigorously promotes the economic virtue of spending and investing in the defense industry (EDA, 2015), it is not unreasonable to anticipate that the domestic military armament industry (with its workforce) could easily be re-tooled to serve the new commercial needs of the enhanced public transit system. It would be an Orwellian insanity to effect perpetual wars in order to ensure national economic prosperity. Effectively, a new „environmental defense" economy would replace the old "military defense" economy. The old driving force of a profit generation could even remain unchanged. Net massive unemployment would not be likely to occur because of this proposed military demobilization through intentional budget diversion.

The suggested reduction in motor fuel consumption would definitely affect the national revenue. In 2010, the German national revenue was about $€ 323$ billion, of which $\sim € 36$ billion was collected from nonVAT motor fuel consumption taxes (EC, 2014). The estimated VAT (at 19\% tax on "cost of goods + tax") revenue would be $\sim € 36$ billion additionally. However, the decline in revenue is not necessarily detrimental in the national budget balance if there is a concomitant reduction in expenditures. Brück et al, (2010) estimated the annualized 2010 cost of the expeditionary war in Afghanistan to be about $€ 3$ billion. After 14 years, the war in Afghanistan is still in progress without any definitive end in sight. The cancellation of this avoidable annual foreign war expenditure would be a good starting point to finance the aggressive action required to mitigate the looming climate-change catastrophe. Furthermore, the Financial Transaction Tax (FTT), which came into effect on January 1, 2016, could provide additional offsetting revenue to finance enhanced public transit. The EC (2015) has estimated that the revenue to be provided by the FTT would be that of the order of $0.4 \%$ to $0.5 \%$ of the Gross Domestic Product (GDP). In 2010, Germany's GDP was €2,576 billion; the FTT revenue would have been $€ 10$ billion to $€ 13$ billion. It is interesting to note that the EUharmonized FTT rate is set to be $0.1 \%$ of the value of the transactions of all types of financial instruments except derivatives $(0.01 \%$ rate). The VAT rate in Germany has been $19.0 \%$ since 2001 . There is evidently considerable room to deploy the FTT tool to create even more recurring funds for „environmental defense”.

\section{Global challenge}

Superficially, the EU-promulgated goal of the mitigation of GHG emission through a greater use of biofuels and the EU-subscribed goal to improve the livelihood of people in developing countries are complementary. A. Leopold and K. Dietz (2012) have however commented that in practice, these two goals for humanity are contradictory. J. Franco, L. Levidow, D. Fig, L. Goldfarb, M. Hönicke and M. L. Mendonça (2010) have also highlighted the practical dilemma of reconciling the multi-tier issues of the environmental, social and economic dimensions of the EU biofuel policy. In the context of the founding principles of the European Union (EU, 2015), the political economy of neoliberalism undermines the implementation of these apparently good intentions. For example, the persistent large consumption of biofuels in the EU necessitates the deployment of large-scale plantations (for economy of scale) to deliver an "abundant cheap" biofuel feedstock to the EU. Because commercial enterprises are required to maximize a profit for their shareholders (Friedman, 1970), the unfettered exploitation of people and the plundering of natural resources are inevitable results. Tinkering with the EU policy reforms to include, among other things, "the meaningful consideration of the social dimensions" and "improving democratic decision making" would not be sufficient to rectify this contradiction. Fairness (in fuels) is a construct in relativity. Who decides what is fair? The economic root of this societal problem has to be addressed in the search of a practicable solution. Unfortunately, it would be just wishful thinking that the neoliberal economic principle of the foundation of the EU could be overturned in the near future by the large middle-income segment of the EU society. 
The EU could assume a global leadership role by undertaking a very different pathway in implementing a severe self-imposed reduction in motor fuel consumption. In parallel, the global action of the EU should also include the provision of meaningful assistance for LEDCs to create biofuel for local uses, rather than for creating new export to the EU in support of its accustomed ostentatious energyintensive way of life.

For many years already, the EU has officially endorsed the support of developing countries in the transition to biomass-derived and other renewable energy systems. The assistance is, however, not free or entirely benevolent. For example, the UK, an once leading EU member state, will be demanding the repayment of its climate-change aid to poor countries, when its own (British) per capita emission is among the highest in the World (Vidal, 2008). This policy approach remains unchanged. The net outcome is that the recipient (i.e. a less-developed country) will be saddled with a more avoidable financial debt. The donor benefits from, among other things, the importation of a cheap feedstock and the secured export of the services and manufactured goods for the new biofuel industry in the LEDCs. There is certainly no compelling reason for less-developed countries to assume a yet higher financial burden in support of the ostentatious energyintensive lifestyle enjoyed by EU member states.

\section{Global development}

A. Wong (2010) has previously proposed a generouslyendowed Global Bioenergy Development Fund for the people of LEDCs to create their own indigenous biofuel for a) offsetting costly petroleum imports and $b$ ) reducing the avoidable emission of $\mathrm{CO}_{2}$ to the atmosphere from road transportation fuels. This scheme would be workable, if and only if there were no financial incentive for undertaking „new lucrative biofuel export trade to the EU". The present modality of biofuel developments is based on the premise that there would be tangible gains for the people of the LEDCs. In practice, only EU private enterprises and their ruling-class collaborators in less-developed countries are the economic beneficiaries. Certainly, people should not be toiling, albeit in producing yet another exportable agricultural commodity, to support the accustomed „luxurious" lifestyle of the Europeans.

Because of the low level of the per capita consumption of transportation fuel and the different modality of enterprise development, there should be little or no disruption caused by land use allocation for biofuel production. It may be emphasized again that the elimination of the "economic opportunity" to export fuel-based materials to the EU would greatly mitigate the underlying causes of severe societal and ecological destruction to the biofuel-feedstock producer countries. If there were no importation of biodiesel and the ethanol feedstock by the EU, there would be no relentless commercial pressure to "drive down the cost" of these feedstocks imported from LEDCs. The underlying force of destroying the indigenous social and environmental well-being in the fulfillment of the EU biofuel goal could thus be neutralized.

\section{Global engagement}

Another beneficial outcome of this approach is that the people of less-developed countries would be engaged, with the pro-active assistance of the EU, in the concerted global reduction in $\mathrm{CO}_{2}$ emission. At present, many people in LEDCs see the reduction in $\mathrm{CO}_{2}$ emission to be largely a trivial pursuit of „rich nations"; many people in LEDCs just struggle to merely survive from day to day. The present EU biofuel strategy has only delivered a reduction in food security and the perpetuation of economic deprivation.

A reduction in GHG emission for the mitigation of rapid climate change should be an undertaking of all citizens throughout the World. The highest burden should rightly be shouldered by the citizens of the EU as well as by those in other developed countries as they are the principal emitters. There is a doubt that, in terms of an absolute emission, China and India, for example, belong to the larger emitters of GHG. It is, however, grossly unjust to penalize the people of LEDCs for their frugal per capita use of petroleum-based motor fuels. S. G. Spierre, T. P. Seager and E. Selinger, (2013) suggested that the placement of the universal limit of GHG reduction would unequally inhibit the advancement of less economically-developed countries on the HDI 
scale. The responsibility for GHG mitigation would be leveled if the per capita emission were re-balanced for all. In the present predicament of global warming and the need for an urgent remedial action, there is no $a$ priori reason why the Europeans should continue to enjoy the ostentatious energy-intensive lifestyle while citizens in the other parts of the world should continue to live in depravity and poverty. The EU needs to disengage from the neoliberal economic paradigm in order to provide significant unselfish leadership in helping to save the World from the impending climatechange catastrophe.

\section{CONCLUSION}

The major findings of this study are:

- Even at the level of just $10 \%$ biofuel content in motor fuels by 2020, considerable negative consequences have already been created in the global feedstock supply chain. Continued insatiable rising demand for motor fuels in the EU will only exacerbate the externalities of the irreparable social, cultural and economic disorders in less-developed countries which produce feedstocks and/or finished biofuel. It is obvious that no amount of bio-oil crop could ever be grown in sufficient quantities to fulfill the ever-increasing demand for biofuel in the transportation sector of the EU;

- The present reliance on the biofuel strategy has little or no possibility of realizing any significant reduction in GHG emission in the transportation sector.

Radical measures are required to afford an effective reduction in the per capita $\mathrm{CO}_{2}$ emission. There are few, if any, policy undertakings in the EU for reducing the absolute demand for transportation fuel in the EU. An absolute reduction in motor fuel consumption does not necessarily require the lowering of the quantity and quality of the accustomed lifestyle. If the EU were sincerely interested in remedying the rapid climate change caused by its transportation sector, then greatly enhanced public transit systems would be the best practicable path forward in reducing the absolute consumption of motor fuels and the consequent GHG emission. No new taxes would need to be imposed in order to regulate public behavior. Only the re-allocation of the government budgetary resources would be required to support a "free" public transportation system.

A reduction in GHG emission has no national boundaries. There is a dire need for a new strategy to deliver the meaningful levels of technical and economic assistance to LEDCs for the communityscale production of biofuel for a local use. Unselfish investment in overseas biofuel crop planting, modelled on the basis of small-scale enterprises, would improve the local social economy at the community level as well as engage the people of developing countries in the global action on $\mathrm{CO}_{2}$ reduction. Concomitantly, the unbridled expansion of biofuel feedstock production in LEDCs will automatically be stopped when there is no demand for the importation of such goods by the EU.

\section{ENDNOTES}

1 In this paper, $\mathrm{CO}_{2}$ emission is used interchangeably with greenhouse gas (GHG) emission.

2 The HDI is widely recognized to be as measure of the wellbeing of people. It is devised to reflect a specific capitalistic free-market ideology, without an adequate consideration of, among other things, the cultural elements and the prevailing social and economic disparity within a country. It may be noted that the HDI concept is not applicable to Cuba or the Democratic People's Republic of Korea, which have very different economic systems. Despite its imperfections, the $\mathrm{HDI}$ is the best available measure to be used in the present study.

3 Indirect land use conversion considers an impact on the intensification of agriculture so as to cause a greater CHG emission, the conversion of "unproductive" land on the example biodiversity and food cropping potential, and changes in the consumption of cropping inputs such as fertilizers, water, motor fuels and labor force. In contrast, direct land use conversion denotes direct effects on the use of the currently productive as well as "unproductive” land for new biofuel crops. An additional description of the broad classification is given elsewhere (Fritsche, Sims \& Monti, 2010). 
4 In effect, the biofuel made by the application of "older technologies with higher negative land-use attributes" would not be disqualified as an approved biofuel in the near future.

5 The proportion of the gasoline-to-diesel used for road transport can be influenced to a large extent by the prevailing government fuel tax policies. In some countries such as France, fuel tax on diesel is purposely set to be lower than that on gasoline, this being so in order to promote the use of diesel for national political and economic reasons.

6 The EU-15 member states were chosen for an illustration in this study as the developmental statuses of these states are substantially more advanced than those of the new member states of the post-2004 period.

7 F. Braudel (1977) aptly observed that „capitalism only triumphs when it becomes identified with the state, when it is the state".

8 At a constant $2 \%$ real economic growth, annually.

9 Assuming that motor fuel consumption in the future years is going to be proportional to the population growth. The demographic projection for the EU-15 was sourced from the Eurostat data (http://ec.europa.eu/eurostat/)

10 Deutsche Bahn AG is presently owned $100 \%$ by the Bundesrepublik Deutscheland. In 2013, the total revenue of Deutsche Bahn AG was about $€ 39$ billion, of which rail passenger transport accounted for about 33\% of the total revenue (http://www.deutschebahn.com).

11 The original SIPRI data reported in US\$; the ECB annual currency exchange rate: $€ 1.00=$ US\$1.33362 in 2010.

\section{REFERENCES}

Ahlgren, S., \& Di Lucia, L. (2014). Indirect land use changes of biofuel production - A review of modeling efforts and policy developments in the European Union. Biotechnology for Biofuels, 7, Article number 35. doi: 10.1186/1754-6834-7-35

Anon. (2008). Tierras destinadas a víctimas del conflicto serán dadas a particulares por MinAgricultura e Incoder. El Tiempo - Colombia, 10 February. Retrieved February 24, 2008, from http://www.eltiempo.com/

Anon. (2014). MP Tigipko: Ukraine turning into resourcesupplying appendage of Europe. Interfax - Ukraine News Agency - Ukraine, 02 October. Retrieved November 16, 2014, from http://en.interfax.com.ua/news/general/226662.html

Borras, Jr. S. M., McMichael, P., \& Scoones, I. (Eds.), (2011). The
Politics of Biofuels, Land and Agrarian Change. New York, NY: Oxford, Routledge.

Braudel, F. (1977). Afterthoughts on Material Civilization and Capitalism. The Johns Hopkins Symposia in Comparative History. Baltimore, USA: The Johns Hopkins University Press.

Broch, A., Hoekman, S. K., \& Unnasch, S. (2013). A review of variability in indirect land use change assessment and modeling in biofuel policy. Environmental Science \& Policy, 29, May, 147-157. doi:10.1016/j.envsci.2013.02.002

Brodzinsky, S. (2013). Guatemala's sugar cane land rush anything but sweet for corn growers. The Guardian, 26 June. Retrieved June 26, 2013, from http://www.theguardian.com/ global-development/2013/ jun/26/ guatemala-sugar-landcorn

Brück, T., de Groot, O. J., \& Schneider. F. (2011). The economic costs of the German participation in the Afghanistan war. Journal of Peace Research 48(6), 793-805. doi: $10.1177 / 0022343311419544$

de la Fuenete Layos, L. A. (2007). Passenger mobility in Europe. Transport Report 87, Cat. No. KS-SF-07-087-EN-N, Statistics in Focus. Luxembourg: EUROSTAT.

De Wit, M., Faaij, A., Fischere, G., Prieler, S., \& van Velthuizen, H. (2007, May.). The potential of European biomass resources and related costs in the EU-27 and the Ukraine. Paper presendet at the $15^{\text {th }}$ European Biomass Conference, Berlin, Germany.

European Commission - EC. (2009). Directive 2009/28/EC of the European Parliament and of the Council of 23 April 2009 on the promotion of the use of energy from renewable sources and amending and subsequently repealing Directives 2001/77/EC and 2003/30/EC.

European Commission - EC. (2014). Excise Duty Tables. Ref 1040, July, 2014. Brussels: European Commission, Directorate-General Taxation and Customs Union. Retrieved May 18, 2015, from http://ec.europa.eu/taxation_customs/ index_en.htm\#

European Commission - EC. (2015). Taxation on the financial sector. Brussels: European Commission, DirectorateGeneral Taxation and Customs Union. Retrieved May 22, 2015, from http://ec.europa.eu/taxation_customs/taxation/ other_taxes/

European Defence Agency - EDA. (2015). The economic case for investing in Europe's defence industry. 20 January. Retrieved May 6, 2015, from http://www.eda.europa.eu/docs/defaultsource/eda-factsheets/2015-01-20- factsheet_economic-case_ 
high

European Union - EU. (2015). The founding principles of the Union. Retrieved May 01, 2015, from http://europa.eu/scadplus/ constitution/objectives_en.htm

Fischer, G., Prieler, S., \& van Velthuizen, H. T. (2007, May). Europe's land resource potential for biofuel production. Paper presendet at the $15^{\text {th }}$ European Biomass Conference, Berlin, Germany.

Franco, J., Levidow, L., Fig, D., Goldfarb, L., Hönicke, M., \& Mendonça, M. L. (2010). Assumptions in the European Union biofuels policy: frictions with experiences in Germany, Brazil and Mozambique. The Journal of Peasant Studies, 37(4), 661-98. doi: 10.1080/03066150.2010.512454

Friedman, M. (1970). The social responsibility of business is to increase its profits. The New York Times Magazine, September 13.

Fritsche, U. R., Sims, R. E. H., \& Monti, A. (2010). Direct and indirect land-use competition issues for energy crops and their sustainable production - an overview. Biofuels, Bioproducts and Biorefining, 4(6), 692-704. doi: 10.1002/bbb.258

Government of the Hong Kong Special Administrative Region - GHK-SAR (2014). Annual Transport Digest - 2014. Retrieved November 17, 2014, from http://www.td.gov.hk/mini_site/ atd/2014/en/section1.html

Havlík, P., Schneider, U. A., Schmid, E., Bottcher, H. et al. (2011). Global land-use implications of first and second generation biofuel targets. Energy Policy, 39(10), 5690-5702. doi:10.1016/j. enpol.2010.03.030

Hennecke, A. M., Faist, M., Reinhardt, J., Junquera, V., Neeft, J., \& Fehrenbach, H. (2013). Biofuel greenhouse gas calculations under European Renewable Energy Directive - A comparison of the BioGrace tool vs. the tool of the Roundtable on Sustaianble Biofuels. Applied Energy, 102, February, 55-62. doi:10.1016/j.apenergy.2012.04.020

Intergovernmental Panel on Climate Change - IPPC. (2014). Climate Change 2014: Mitigation of Climate Change. Contribution of Working Group III to the Fifth Assessment Report of the Intergovernmental Panel on Climate Change. Cambridge: Cambridge University Press.

Kenfield, I. (2008). Brazil's ethanol plan breeds rural poverty, environmental degradation. Montreal: Centre for Research on Globalization. Retrieved January 28, 2009, from http://www. globalresearch.ca/

Klawitter, N. (2014). The dirty business of palm oil. Der Spiegel, 5 February. Retrieved May 4, 2014, from http://www.spiegel. de/international/world/indonesian-villagers-driven-from- villages-in-palm-oil-land-theft-a-967198.html

Klein, N. (2007). The Shock Doctrine: The rise of disaster capitalism. Toronto, Canada: Vintage.

Klein, N. (2014). This changes everything: Capitalism vs. the climate. Toronto, Canada: Knopf.

Leopold, A., \& Dietz, K. (2012). Transnational contradictions and effects of Europe's bioenergy policy: Evidence from Sub-Saharan Africa. Fair Fuels? Working Paper 4. Berlin, Germany: Freie Universität.

Magdoff, F. (2008). The political economy and ecology of biofuels. Monthly Review, 60(3). Retrieved October 7, 2015, from http://monthlyreview.org/2008/07/01/the-politicaleconomy-and-ecology-of-biofuels/

Mathiesen, K. (2013). Food-based biofuels allowance to rise by $50 \%$ under EU plans. The Guardian - UK, 29 November. Retrieved November 29, 2013, from http://www.theguardian. com/environment/2013/nov/29/food-based-biofuels-riseeuropean-union-crops

Spierre, S. G., Seager, T. P., \& Selinger, E. (2013). The diminishing returns to the 2010 human Development Index: Implications for climate policy and sustainable development. Journal of Sustainable Development, 6(6), 34-47. doi: http://dx.doi. org/10.5539/jsd.v6n6p34

Stockholm Environment Institute - SEI. (2008). Partnerships for Bioenergy in Africa. Special Issue. Renewable Energy for Development 21(1), 1-8.

Stockholm International Peace Research Institute - SIPRI. (2014). Trends in World Military Expenditure, 2013. Retrieved May 6, 2015, from http://bboks.sipri.org/files/FS/SIPRIFS1404. pdf

Teeple, G. (1995). Globalization and the decline of social reform. Toronto, Canada: Garamond Press.

United Nations Development Programme - UNDP. (2014). Human Development Index. www.undp.org. Data published annually.

United Nations Statistics Division - UNSD. (2015). Energy Statistics Data Base. http://unstats.un.org/ Data updated annually.

van der Horst, D., \& Vermeylen, S. (2011). Spatial scale and social impacts of biofuel production. Biomass and Bioenergy, 35(6), 2435-2443. doi:10.1016/j.biombioe.2010.11.029

Vidal, J. (2008). UK demands repayment of climate aid to poor nations. The Guardian UK, 16 May. Retrieved May 28, 2008, from http://www.guardian.co.uk/environment/ 2008/ 
may/16/climatechange.internationalaidanddevelopment

Wong, A. (2008, September). Societal and environmental aspects of supplying biomass oil from developing countries for the fuelling of EU diesel vehicles. Paper presendet at the 4th International Conference on Biomass for Energy, Kiev, Ukraine.

Wong, A. (2010, May). The Global Bioenergy Development Fund - a path forward for social justice in the mitigation of anthropogenic emission of greenhouse gases. Paper presented at the World Energy 2010 Conference, Jönköping, Sweden.

Wong, A., \& Ching, D. L. K. (2009). De-globalization of biofuel trade for social justice and cleaner environment. Paper presented at the CIOSTA XXXIII Conference, Reggio Calabria, Italy, 1719 June.

Received on $2^{\text {nd }}$ June 2016, after two revisions, accepted for publication on $22^{\text {nd }}$ August 2016.

Published online on $26^{\text {th }}$ August 2016.

Alfred Wong is the Technical Director at Arbokem Inc., an independent technology research and management company based in Vancouver, Canada. He engages in research on the social, environmental and technology aspects of biomass energy systems.

\title{
DRUŠTVENA EKONOMIJA POTROŠNJE TEČNOG GORIVA U DRUMSKOM SAOBRAĆAJU U EVROPSKOJ UNIJI
}

\author{
Alfred Wong \\ Arbokem Inc., Vancouver, Canada
}

Da bi Evropska unija (EU) ostvarila cilj potrošnje 10\% bio-goriva za sva motorna vozila u zemljama EU, do 2020, trebalo bi da se uvezu znatne količine bio-goriva i osnovnih sirovina bio-goriva, i to, uglavnom, iz zemalja u razvoju, sa jeftinom radnom snagom. Međutim, možda bio-goriva i njegovih osnovnih sirovina nikada neće biti u količinama dovoljnim za zadovoljenje rastuće tražnje za bio-gorivom u drumskom saobraćaju u EU, čak ni u uslovima rastuće efikasnosti potrošnje goriva motornih vozila. Arogantna politička ekonomija neoliberalizma predstavlja prepreku za realizaciju efektivnog i pravičnog smanjenja emisije gasova sa efektom staklene bašte. Rešavanje dualnih problema prekomerne upotrebe motornih goriva i emisije gasova sa efektom staklene bašte zahteva drugačiju strategiju.

Ključne reči: bio-gorivo, energija, iskorišćavanje, gas sa efektom staklene bašte, životni stil, drumski saobraćaj

JEL Classification: O33, 052, P28, Q54 